\title{
Pengaruh Senam Lansia Terhadap Tekanan Darah Yaitu Hipertensi
}

Siska Tumuwo

\author{
IIK Surya Mitra Husada (Ilmu Kesehatan Masyarakat)
}

\section{Tumuwosiskaa27@gmail.com}

\begin{abstract}
Abstrak
Masalah kesehatan yang sering dialami oleh lansia salah satunya adalah hipertensi. Hipertensi atau tekanan darah tinggi merupakan salah satu contoh penyakit degeneratif. Penyakit darah tinggi atau hipertensi adalah suatu peningkatan abnormal tekanan darah dalam pembuluh darah arteri secara terus menerus lebih dari satu periode. Tingginya angka kejadian hipertensi terutama pada lansia. Salah satu cara untuk menurunkan hipertensi pada lansia dengan rutin mengikuti senam lansia. Control tekanan darah yang ketat pada lansia berhubungan dengan pencegahan terjadinya peningkatan tekanan darah yang tidak terkendali. Aktivitas fisik seperti senam pada usia lanjut yang dilakukan secara rutin akan meningkatkan kebugaran fisik, sehingga secara tidak langsung senam lansia dapat meningkatkan fungsi jantung dan menurunkan tekanan darah serta mengurangi resiko penumpukan lemak pada dinding pembuluh darah sehingga akan menjaga elastisitasnya.
\end{abstract}




\section{Latar Belakang}

Usia harapan hidup pada lansia di Indonesia semakin menurun dikarenakan berbagai penyakit yang di derita salah satu diantaranya adalah penyakit hipertensi. Hipertensi adalah keadaan seseorang yang mengalami peningkatan tekanan darah diatas normal sehingga mengakibatkan peningkatan angka morbiditas maupun mortalitas, tekanan darah fase sistolik $140 \mathrm{mmHg}$ menunjukkan fase darah yang sedang dipompa oleh jantung dan fase diastolik $90 \mathrm{mmHg}$ menunjukkan fase darah yang ke jantung (Triyanto, 2014). Hipertensi merupakan masalah kesehatan yang cukup berbahaya di seluruh dunia.. Proses terjadinya penuaan penduduk dipengaruhi oleh pelayanan kesehatan, gizi, sosial ekonomi dan tingkat pendidikan atau pengetahuan. Secara global populasi lansia diprediksi terus mengalami peningkatan (Kemenkes RI, 2018). Prevelensi penderita hipertensi tidak hanya terjadi di negara maju tetapi juga di negara berkembang. Senam lansia pada usia lanjut yang dilakukan secara rutin akan meningkatkan kebugaran fisik, sehingga secara tidak langsung senam dapat meningkatkan fungsi jantung dan menurunkan tekanan darah sehingga akan menjaga elastisitasnya.

Kasus hipertensi pada lansia di Indonesia pada tahun 2018 yaitu 63,2\% (Riskesdas, 2018). Profil Kesehatan Jawa Tengah (2015) menunjukkkan prevelensi hipertensi di Jawa Tengah sebesar 17,74\%, sedangkan untuk wilayah Boyolali sendiri prevelensi hipertensi sebesar 11,82\%. Di Propinsi Jambi penyakit hipertensi menempati urutan ketiga dari 10 penyakit terbesar pada tahun 2013, yaitu sebanyak 80.381 kasus atau sekitar 12,63\%. Sedangkan di Kota Jambi selama tahun 2014 terdapat 35.341 kasus hipertensi dan 20.621 diantaranya diderita oleh lansia. Disisi lain jantung akan melatih otot dalam berkontraksi sehingga kemampuan pemompaanya akan selalu terjaga (Nugroho, 2015).

\section{Kasus / Masalah}

Apa pengaruh senam lansia terhadap tekanan darah yaitu hipertensi?

Menurut penelitian yang dilakukan di Panti Asuhan Tresna Wedha Budi Luhur Jambi diketahui bahwa sebelum senam lansia TD systole adalah 153,49 $\mathrm{mmHg}$ dan diastole $86.81 \mathrm{mmHg}$. Setelah senam rata-rata TD sistole mengalami penurunan 
menjadi 145,38 mmHg. Demikian juga TD diastole mengalami penurunan 78,11 mmHg (M Dody Izhar, 2017).

Menurut penelitian yang dilakukan di daerah Blembem Jawa Tengah dengan jumlah 40 responden diketahui bahwa sebelum melakukan senam lansia diperoleh nilai minimum sebesar 140/80 $\mathrm{mmHg}$, maksimum 180/100 $\mathrm{mmHg}$ dan nilai ratarata sebesar 158/96 mmHg (hipertensi ringan), sedangkan tekanan darah lansia setelah dilakukan senam lansia diperoleh nilai minimum 130/70 mmHg, maksimum 140/80 $\mathrm{mmHg}$ dan nilai rata-rata sebesar 146.88/88.75 mmHg (hipertensi ringan (Wahyuningsih S, Hutari Puji A, 2017).

\section{Tinjauan Pustaka}

Lansia adalah seseorang yang telah memasuki tahap akhir dari fase kehidupan. Kelompok yang dikategorikan lansia ini akan mengalami suatu proses yang di sebut proses penuaan (Wahyudi, 2008). Lansia adalah proses normal menjadi tua tanpa suatu kriteria usia tertentu dimana usia itu mengalami berbagai macam perubahan baik perubahan molekul sel dan perubahan kemampuan fungsi organ (Stanly dan Patricia, 2007). Hipertensi adalah keadaan seseorang yang mengalami peningkatan tekanan darah diatas normal sehingga mengakibatkan peningkatan angka morbiditas maupun mortalitas, tekanan darah fase sistolik $140 \mathrm{mmHg}$ menunjukkan fase darah yang sedang dipompa oleh jantung dan fase diastolik $90 \mathrm{mmHg}$ menunjukkan fase darah yang ke jantung (Triyanto, 2015). Tekanan darah akan meningkat setelah umur 4555 tahun, dinding arteri akan mengalami penebalan oleh adanya penumpukan zat kolagen pada lapisan otot, sehingga pembuluh darah akan berangsur-angsur menyempit menjadi kaku (Setiawan, Yunani \& Kusyati, 2014). Tingginya angka hipertensi pada lansia salah satu penyebabnya adalah kurangnya olahraga atau senam lansia. Factor penyebab hipertensi adalah factor genetic, factor jenis kelamin dan factor usia. Senam lansia adalah olahraga ringan dan mudah dilakukan, tidak memberatkan yang diterapkan pada lansia.senam lansia merupakan suatu aktivitas fisik yang terutama bermanfaat untuk meningkatkan dan mempertahankan kesehatan dan daya tahan jantung, paru, peredaran darah, otot dan sendi. 


\section{Pembahasan}

Hasil dari jurnal menyatakan bahwa senam lansia dapat menurunkan tekanan darah baik sistole maupun diastole sesuai dengan teori. Efek dari olah raga lansia atau senam lansia yang dilakukan secara teratur dapat melancarkan peredaran darah sehingga dapat menurunkan hipertensi.

\section{5. kesimpulan}

Senam lansia sangat penting bagi lansia tidak hanya untuk kebugaran tetapi juga untuk menurunkan tekanan darah yaitu hipertensi. Dengan catatan dilakukan dengan berulang dan menjaga kesehatan dengan gaya hidup yang sehat.

\section{Daftar Pustaka}

Dinas Kesehatan Propinsi Jambi. Profil Dinas Kesehatan Propinsi Jambi Tahun 2014. Jambi 2015.

Dinkes Provinsi Jawa Tengah (2015). Profil Kesehatan Provinsi Jawa Tengah 2015.

Dody, M. 2017. Pengaruh Senam Lansia Terhadap Tekanan Darah di Panti Sosioal Tresna Werdha Budi Luhur Jambi.

Kemenkes RI, 2018

Nugroho. (2015). Keperawatan geronik dan geriatrik edisi 3. Jakarta : EGC

Riskesdas. 2018. Prevalensi hipertensi (Diagnosa Dokter) Pada Penduduk Umur $\geq 18$ Tahun Menurut Karakteristik, 2018.

Stanley, M \& Beare, P. G. (2006). Buku ajar keperawatan geronik. Jakarta : EGC 